\title{
Redesign plans assailed
}

\section{Washington}

THE space station last week came under new attack from lawmakers who fear that it is becoming more bus station than scientific laboratory.

At a hearing to examine the 1991 budget for the National Aeronautics and Space Administration (NASA), legislators warned NASA that changing the project's design to accommodate the president's proposal to send humans to the Moon and Mars risked breaking research commitments and alienating international partners.

"We were sold the space station partly on its ability to do microgravity research", Representative Bill Green (Republican, New York) told the President's science adviser, D. Allan Bromley. If the space station is to be used as a "transportation node" for interplanetary travel or orbital missions, Green pointed out, the jostling of men and machines on board could make low-gravity science difficult.

"What we have now is a space station that we are struggling to keep as a scientific laboratory", added Representative Bob Traxler (Democrat, Michigan), chairman of the appropriations subcommittee that funds NASA. "Our international partners' first area of concern is microgravity research. That should send us a signal." Some current NASA scenarios would allow for as little as two years of high-quality microgravity time before the station is adapted to serve as a construction and servicing hub for other proposed missions. Ian Pryke, head of the Washington office of the European Space Agency (ESA), confirms that basic science is indeed ESA's top priority, but that it is not inconceivable that the agency WHITEHEAD INSTITUTE

\section{Fink appointed director Boston}

THE Whitehead Institute for Biomedical Research in Cambridge, Massachusetts, has named Gerald R. Fink as its new director. Fink, who will succeed David Baltimore in the post on 1 July, is currently American Cancer Society professor of genetics at the Whitehead Institute and in the department of biology at Massachusetts Institute of Technology. One of the original members of the Whitehead Institute, Fink pioneered the use of yeast as a model for genetic research, and was the first to develop a method to introduce foreign genes into yeast. An outspoken proponent of increased support for research in plant biology, Fink is a member of the National Academy of Sciences and the American Academy of Arts and Sciences as well as a former president of the Genetics Society of America. Seth Shulman could want a part in a Moon/Mars project as well.

"We entered into a partnership to build an orbiting laboratory", Pryke says. But he says that ESA, which along with Canada and Japan represents most of the international component of the project, is waiting to see how plans for a Moon/Mars project develop before it decides whether to ask NASA to guarantee adequate resources for science.

One possible solution is to relegate microgravity science to smaller modules that orbit near the station but are not physically connected to it. The ESA ManTended Free Flyer is one such module and is already scheduled for launch in the late 1990s. NASA spokesman Mark Hess says the space agency is considering further separation of construction and science on the space station, a redesign that could change the project's concept from that of a single structure to an orbiting swarm of smaller modules.
But even traditional congressional supporters of the project are growing wary of NASA's willingness to change its basic configuration seemingly at will. "It troubles me that [these issues] are being

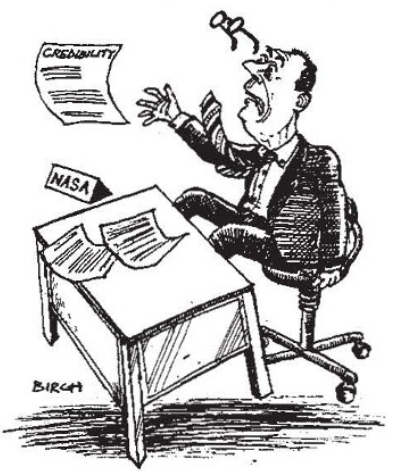

looked at six years after [the space station] was approved. We're building it, then looking for a purpose for it", Green said last week. Traxler warned Bromley that the eleventh-hour redesigns are "destroying [the administration's] credibility and harming science".

G. Christopher Anderson

\section{NASA's plans too timid}

\section{Washington}

THE US National Research Council (NRC), in a report published last week, gives a general endorsement to plans put forward by the National Aeronautics and Space Administration (NASA) for accomplishing the voyage to Mars, but also adds its voice, if rather discreetly, to the chorus of critics who believe that NASA is being too timid in its thinking. The NRC suggests that establishing a space station in orbit around Mars would be an easier and safer first goal than going directly to the surface, and argues that too little attention is being paid to human issues, particularly the long-term effects of weightlessness and the possibility of reducing these by using artificial gravity.

The NRC report, produced at the request of Vice-President Dan Quayle in his capacity as chairman of the National Space Council, is a review of NASA's '90Day Study', released last November, in which five strategies for establishing a human presence on Mars were sketched out (see Nature 342, 607; 1989). In all of those plans, after a 'practice' base has been set up on the Moon, a direct journey is undertaken from Earth orbit to the martian surface. The NRC report, however, points out that the descent to the martian surface is likely to be the hardest part of the trip, and recommends that a station in Mars orbit would provide a safe staging post from which the final assault could be mounted. The report chides NASA for placing too much reliance on the feasibility of 'aerobraking', by which spacecraft would descend to Mars beneath vast parachutes.

But the NRC review committee gives little encouragement to the idea, promoted by physicists Edward Teller and Lowell Wood, that a cheap, quick trip to Mars could be made by 'space inflatables' (see Nature 343, 301; 1989). The report observes laconically that the difficulties of turning the idea into practical technology are "underestimated".

David Lindley

- Under pressure from Congress, NASA last week finally released the cost estimates to go with its four-month old 90-Day Study'. NASA expects that the trip to Mars will cost $\$ 541,000$ million (in 1991 dollars) over 30 years, which is $\$ 241,000$ million more than administration officials gave late last year.

To establish a permanently manned base on the Moon by $2001, \$ 100,000$ million will be needed, and maintaining it until 2025 could cost $\$ \mathbf{2 0 8 , 0 0 0}$ million. Visiting Mars twice, culminating in a 600-day stay in 2018 , would take another $\$ 233,000$ million. If the lunar base is not permanently manned, and if only three short visits to Mars are made, the cost falls to $\$ 471$ million.

White House science adviser D. Allan Bromley quickly warned Congress to take the figures with a grain of salt. The ' 90 Day Study' from which the cost estimates come was "a very crude" process, Bromley told legislators on the House appropriations committee. "I wouldn't put any credibility in the numbers that came out of that", he said. G. Christopher Anderson 